\title{
Notes on the ecology and conservation status of key bird species in Nilo and Nguu North Forest Reserves, Tanzania
}

\author{
NATHALIE SEDDON, JONATHAN M. M. EKSTROM, DAVID R. CAPPER, \\ ISABEL S. ISHERWOOD, RAYMOND MUNA, ROBERT G. POPLE, \\ ERNESTI TARIMO and JONAS TIMOTHY
}

\section{Summary}

Ornithological surveys were conducted in Tanzanian submontane forest at Nilo Forest Reserve in the East Usambaras and Nguu North Forest Reserve in the Nguu Mountains in July-September 1995. Information on the ecology of poorly known bird species of conservation interest was collected and combined with previously published information to assess their conservation status. Sixteen species of conservation interest were recorded during fieldwork, including five Vulnerable (Usambara Eagle Owl Bubo vosseleri, East Coast Akalat Sheppardia gunningi, Amani Sunbird Anthreptes pallidigaster, Banded Green Sunbird Anthreptes rubritorques and Usambara Weaver Ploceus nicolli); three Near-threatened (Southern Banded Snake Eagle Circaetus fasciolatus, Fischer's Turaco Tauraco fischeri and Moreau's Sunbird Nectarinia moreaui); one regionally Endangered (Southern Hyliota Hyliota australis); one regionally Vulnerable (Uluguru Violet-backed Sunbird Anthreptes neglectus), two regionally Near-threatened (Lemon Dove Aplopelia lavata and Evergreen Forest Warbler Bradypterus barratti); and 10 in total as restricted-range species (Fischer's Turaco, Usambara Eagle Owl, Sharpe's Akalat Sheppardia sharpei, Red-capped Forest Warbler Orthotomus metopias, Spot-throat Modulatrix stictigula, Amani Sunbird, Banded Green Sunbird, Moreau's Sunbird, Kenrick's Starling Poeoptera kenricki and Usambara Weaver). New information on the ecology of these species is presented in this paper. It is recommended that the conservation status of East Coast Akalat and Uluguru Violet-backed Sunbird be changed to globally Near-threatened and regionally Near-threatened, respectively. Should further work confirm that the Usambara race of Southern Hyliota deserves specific status it is strongly recommended that it be considered globally Endangered. All other species recorded should retain their current status and continue to be monitored. The Nguus represented a new locality for several species. Sharpe's Akalat, Spot-throat, Red-Capped Forest Warbler, otherwise widely distributed throughout the east Tanzania, were absent from the Nguus.

\section{Introduction}

In the montane forests of east Tanzania long-term environmental stability has enabled the persistence of relict taxa and has promoted the differentiation of radiating taxa leading to high levels of endemism (Fjeldså and Lovett 1997). This is especially well demonstrated in birds and accordingly these forests fall within 
the Tanzania-Malawi Endemic Bird Area (EBA) (as defined by ICBP 1992). This EBA supports 37 restricted-range bird species, including 31 endemic to the EBA and the endemic genera Udzungwa Forest-partridge Xenoperdix and Mountain robins Modulatrix (Stattersfield et al. 1997). Of these species, 20 have been classified as globally threatened, and five as Near-threatened (Collar et al. 1994).

The ecology and conservation status of many of these endemic forest bird species is extremely poorly known. Therefore, ornithological surveys concentrating on these species were conducted in 1995 in two areas of submontane forest for which previously there existed little avifaunal information: Nilo Forest Reserve (FR) in the East Usambara Mountains, and Nguu North FR in the Nguu Mountains. For a discussion of the importance of these Forest Reserves for the conservation of montane forest birds in Tanzania, an outline of the key threats to the reserves, and practical recommendations for their effective long-term conservation see Seddon et al. (in press). In this paper, we present notes on the ecology of Threatened, Near-threatened and restricted-range bird species. Combining these observations with previously published information, we assess the conservation status of each species and comment on their current official global and regional classification.

\section{Methods and study sites}

Fieldwork was conducted at four sites: Lutindi and Kilanga in Nilo FR, and Gombero and Luago in Nguu North FR (Figure 1). Table 1 gives the fieldwork effort at each site, dates of fieldwork, habitats and altitudes surveyed. For a detailed description of these sites and the methodology used to describe them see Seddon et al. (in press). Diurnal field observations were carried out from semi-permanent transect routes that passed through a cross-section of microhabitats. For each bird observation the identity of the species, number of individuals, age and sex where possible, flocking and foraging behaviour, altitude (to the nearest $50 \mathrm{~m}$ ), location and habitat were recorded. Nocturnal observations of birds were made on well-defined trails or stream beds using torches to detect eye-shine and illuminate birds for identification. To help locate elusive and nocturnal species $1018-\mathrm{m}$ mist-nets were operated at a variety of altitudes and microhabitats. Standard biometric data (age, sex, weight, wing, bill and tarsus lengths) and photographs were taken of all birds caught. Sound-recording and playback were carried out using a Marantz $\mathrm{CP}_{43}$ o tape recorder and a Sennheiser ME66 directional microphone. Using both pre-recorded tapes and field recordings, playback was used to locate shy forest species.

To make within-species comparisons of abundance at different sites we used field observations (visual and/or aural) to provide an encounter rate (number of birds recorded per 100 field-hours, hereafter bhf). These encounter rates have biases imposed by variation in habitat density between sites and differences in species' detectability, and they need to be interpreted with caution. The encounter rates were therefore described in terms of subjective impressions of species' abundance from the field as follows: abundant ( $\geq 20.0 \mathrm{bhf}$ ), common (10.0-19.9 bhf), fairly common (5.0-9.9 bhf), uncommon (1.0-4.9 bhf) and rare (<1.0 bhf). Methods for calculating population densities (e.g. point census and line transect methods, Bibby et al. 1992) were not attempted because many of their underlying 


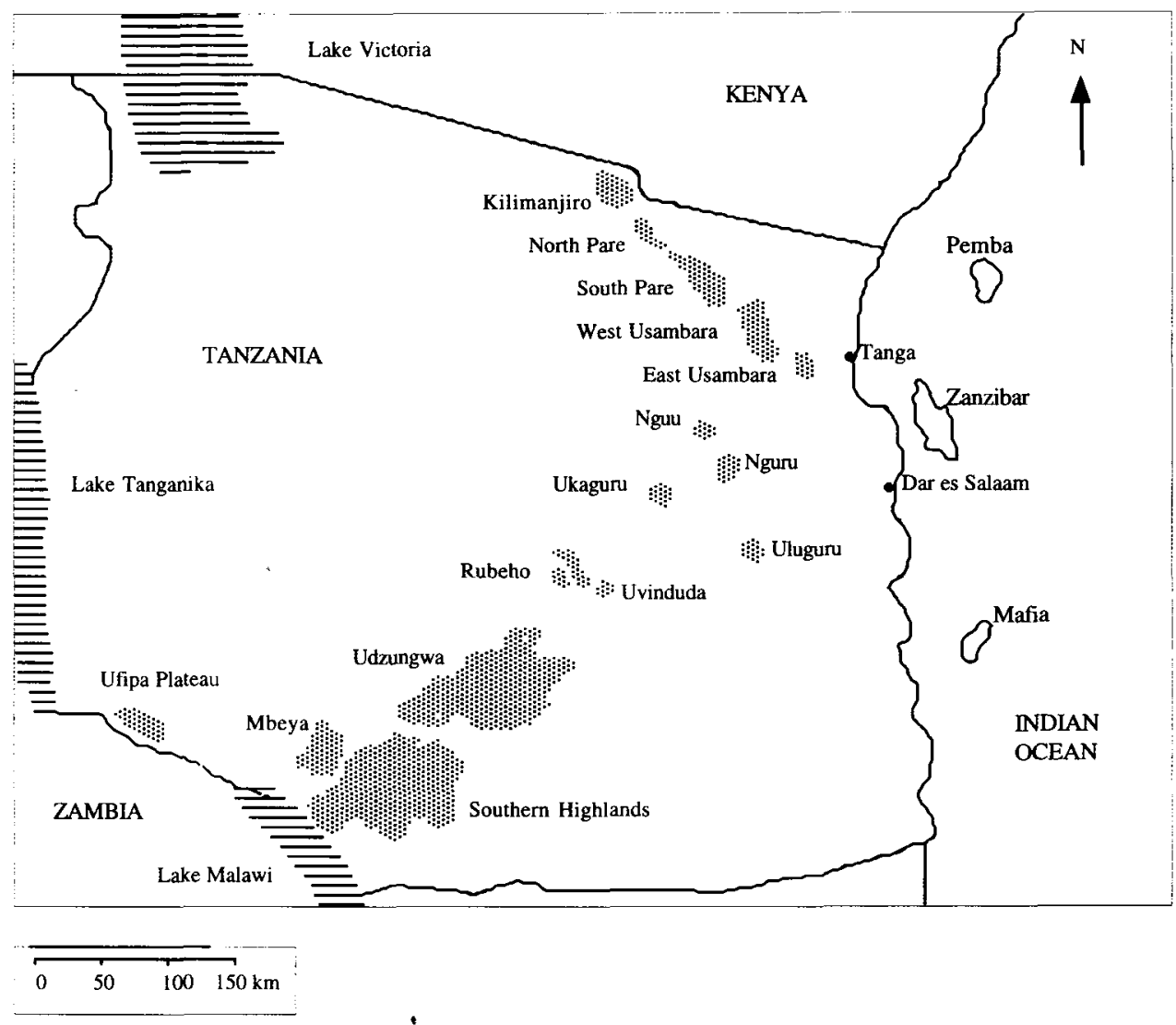

Figure 1. Location of the East Usambaras and Nguus relative to other mountains supporting submontane forest in Eastern Tanzania.

Table 1. Summary of fieldwork effort at study sites

\begin{tabular}{|c|c|c|c|c|c|c|c|c|}
\hline \multirow{2}{*}{$\begin{array}{l}\text { Forest } \\
\text { reserve }\end{array}$} & \multirow[t]{2}{*}{ Site } & \multirow{2}{*}{$\begin{array}{l}\text { Dates } \\
(1995)\end{array}$} & \multirow[t]{2}{*}{ Habitat $^{a}$} & \multirow{2}{*}{$\begin{array}{l}\text { Altitude } \\
\text { (m) }\end{array}$} & \multicolumn{2}{|c|}{ Field-hours $^{\text {b }}$} & \multicolumn{2}{|c|}{ Mist-net hours ${ }^{c}$} \\
\hline & & & & & Diurnal & $\begin{array}{l}\text { Noc- } \\
\text { turnal }\end{array}$ & Diurnal & $\begin{array}{l}\text { Noc- } \\
\text { turnal }\end{array}$ \\
\hline \multirow[t]{4}{*}{ Nilo } & Lutindi & 4 Jul-19 Jul & 1,2 & $1,200-1,500$ & 329 & 11 & 440.5 & 26 \\
\hline & & & $2,3,4$ & $700-1,200$ & & & & \\
\hline & Kilanga & $20 \mathrm{Jul}-31 \mathrm{Jul}$ & 1,2 & $800-1,030$ & 268.5 & 12 & 202.5 & 12 \\
\hline & & & 2,3 & $700-800$ & & & & \\
\hline \multirow{5}{*}{$\begin{array}{l}\text { Nguu } \\
\text { North }\end{array}$} & Gombero & 11 Aug-25 & 1,2 & $1,000-1,550$ & 369 & 22 & 443 & 12 \\
\hline & & Aug & & & & & & \\
\hline & & & 3,4 & 1,000 & & & & \\
\hline & Luago & $\begin{array}{l}28 \text { Aug-8 } \\
\text { Sep }\end{array}$ & 1,2 & $1,140-1,300$ & 316.5 & 18 & 180 & 18 \\
\hline & & & 2,3 & $1,000-1,100$ & & & & \\
\hline
\end{tabular}

a 1 , submontane forest; 2 , secondary forest; 3 , forest edge; 4 , cultivated land.

${ }^{b}$ One field-hour is defined as one hour of field observations carried out by a single person or group of people working together.

${ }^{c}$ One mist-net hour is defined as the operation of a single $18 \mathrm{~m}$ four-panel mist-net for one hour. 
assumptions are violated on a short-term project in dense forest habitat and rugged terrain. Furthermore, an important component of this project was to gather ecological information on poorly known species, which is generally incompatible with more quantitative surveys.

Nomenclature and taxonomy follow Britton (1980) and systematic order is taken from Dowsett and Dowsett-Lemaire (1993). For global conservation status Collar et al. (1994) and Stattersfield et al. (1997) are followed, and threatened status in East Africa (regional status) is taken from Bennun and Njoroge (1996).

\section{Results}

Sixteen species of conservation interest were recorded during fieldwork. Table 2 gives these species' encounter rates, the altitudes at which they were recorded and their conservation status. In the following accounts, new information pertaining to distribution, habitat preferences and ecology is provided, and some status changes are recommended. All the threat codes given in parentheses follow Mace and Stuart (1994).

\section{Southern Banded Snake Eagle Circaetus fasciolatus}

Status and distribution Globally and regionally Near-threatened. Resident in coastal woodlands and forests from south Somalia to Natal and Zululand (Brown et al. 1982). Rarely recorded more than $20 \mathrm{~km}$ inland, but previously found in the East Usambaras near Amani (Moreau 1935, Tye 1993) and recently reported breeding in the lowlands (Hipkiss et al. 1994, Cordeiro and Githiru in press).

Records and ecology All sites: rare. The records in the Nguus represent a new locality for this species. Individuals were observed in intact submontane forest, perching in the canopy at 20-30 $\mathrm{m}$ and soaring above the canopy (contra Brown et al. 1982 who noted that this species rarely soars). The scarcity of records is not surprising given that this species occurs at low population densities throughout its range (N. J. Cordeiro, in litt. 1997). It is possible that these records refer to migrants given the north-south migration in the austral winter (Brown et al. 1982).

Conservation Proven breeding only in lowland forest and coastal woodland (Brown et al.1982, Hipkiss et al. 1994, Corderio and Githiru in press) suggests a preference for this type of habitat. However, these observations indicate that this species may have more complicated habitat requirements (e.g. breeding in the lowlands and overwintering in submontane forest) and it is concluded that until more is known of Southern Banded Snake Eagle's ecology, the most appropriate classification of its conservation status remains Near-threatened.

\section{Lemon dove Aplopelia larvata}

Status and distribution Regionally Near-threatened. Patchily distributed in forests up to 2,500 $\mathrm{m}$ in west Africa and from Ethiopia and Kenya south to Cape Province (Urban et al. 1986). 
Notes on the ecology and conservation status of key bird species

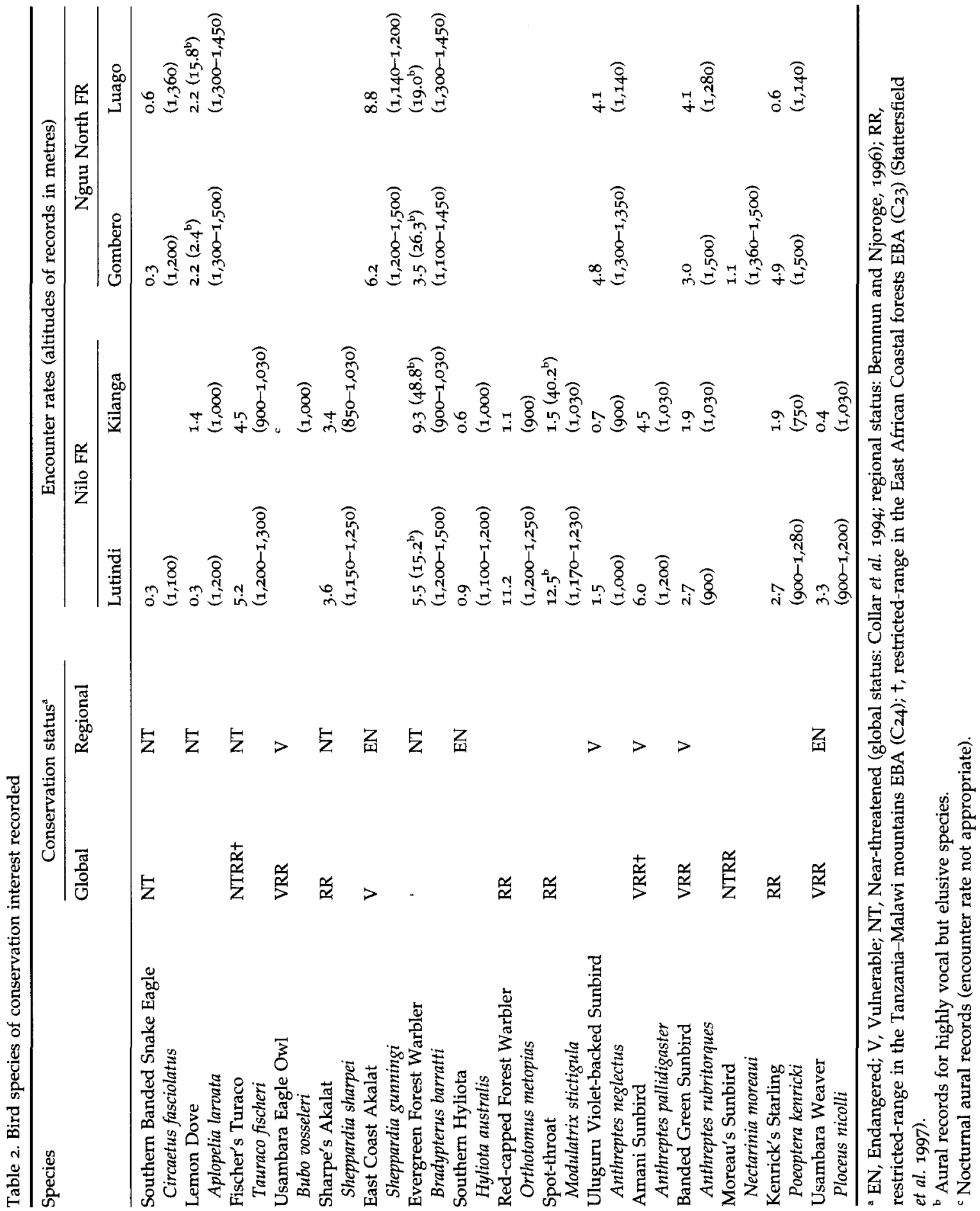


Records and ecology Lutindi: rare (under-recorded); Kilanga: uncommon; Gombero and Luago: uncommon. These records in the Nguus represent a new locality for this species. Individuals were usually observed on the forest floor or making short, noisy flights or perching at $<0.5 \mathrm{~m}$ in low and mid-storey of intact submontane forest.

Conservation Although this dove was only recorded in intact forest, it is known to occur in cultivated areas and is therefore unlikely to be sensitive to habitat degradation at least in the short term. Furthermore, while apparently uncommon in the East Usambaras, there appears to be a significant population in the Nguus. Therefore this species is apparently not under any immediate threat of extinction, although populations in East Africa should continue to be monitored.

\section{Fischer's Turaco Tauraco fischeri}

Status and distribution Globally and regionally Near-threatened; restrictedrange. Widespread and locally common in forest and woodland up to $1,500 \mathrm{~m}$ in Kenya and Tanzania from Boni to Tanga, inland to the Shimba Hills, the East and West Usambaras and Mafi Mountain (Fry et al. 1988).

Records and ecology Lutindi and Kilanga: fairly common. Gombero and Luago: not recorded. It is likely that this species is absent from the Nguus which lie south-west of its known geographic range. Fischer's Turaco was mainly recorded (89.7\% of individuals, $n=29$ ) in the canopy and subcanopy of mature fruiting trees at $15-35 \mathrm{~m}$ in intact submontane forest. Turacos were usually encountered in pairs or small groups (mean group size 2.4 , range $1-5, n=12$ groups), and were frequently observed foraging with other frugivorous birds, e.g. Green Barbet Buccanodon olivaceum, Olive Pigeon Columba arquatrix and Striped-cheeked Greenbul Andropadus milanjensis. However, on four occasions individuals were observed as part of coherent mixed-species flocks comprising insectivorous and frugivorous species including Grey Cuckooshrike Coracina caesia, Olive Woodpecker Mesopicos griseocephalus, Shelley's Greenbul Andropadus masukuensis, Square-tailed Drongo Dicrurus ludwigii, White-tailed Crested Flycatcher Trochocercus albonotatus and Dark-backed Weaver Ploceus bicolor. Individuals were frequently seen running along branches chasing each other or other species whilst emitting a loud, very distinctive "chacking" call which was also given in flight. Other calls included a soft, resonant chuckle and a loud, grating bark similar to that given by Livingstone's Turaco Tauraco livingstonii. This bark was commonly heard at dusk, around $18 \mathrm{~h} 30$, when individuals in pairs called first antiphonally and then simultaneously.

Conservation Other workers have noted that this species survives well in formerly forested areas which retain some trees, and in thickets and wooded gardens (Fry et al. 1988). While this may be true in the short term, these observations suggest some preference for relatively intact submontane forest. Therefore although its range is relatively large, it is likely that this turaco's long-term survival prospects are being compromised by deforestation, and hence Nearthreatened remains a suitable classification of its conservation status. 


\section{Usambara Eagle Owl Bubo vosseleri}

Status and distribution Globally and regionally Vulnerable; restricted-range. Known from a few sites in the Usambaras (Collar et al. 1994), and from one site in the Ulugurus (Hunter et al. 1996). Between 1962 and 1985 there were a mere 19 records from submontane forest at 900-1,300 m mainly from the Amani area of the East Usambaras and Mazumbai in the West Usambaras (Collar and Stuart 1985), with a possible sighting in the Ngurus (Moreau 1964). The taxonomy of the bird is in question. While some authors treat it as a separate species, Bubo vosseleri (e.g. Turner et al. 1991, Sibley and Monroe 1990, Collar et al. 1994), others consider it to be an isolated subspecies of Fraser's Eagle Owl B. poensis, found in west and central Africa (e.g. White 1965, Brown et al. 1982).

Records and ecology Lutindi: not recorded; Kilanga: rare. Gombero and Luago: not recorded (possibly absent). This species was probably overlooked at Lutindi, especially as Cordeiro (in press) recorded it at this site in 1994. Aural records were made on the nights of 26, 27 and 28 July 1995 between 24 hoo and 03 h15 in intact submontane forest. Calls lasted 5-7 seconds and comprised a low-pitched, weak "po-a-po-a-po-a-po-a-po-a", accelerating and then decelerating, declining in pitch. Each phrase was repeated at intervals of 30-6o seconds, up to four times. It matched a recording believed to belong to this species that was made on Mount Mtai in July 1991 (Evans and Anderson 1993).

Conservation These records, together with those of Cordeiro (in press) and Evans et al. (1994) who recorded it at three lowland sites, confirm that Usambara Eagle Owl is widely distributed in the East Usambaras. Given that it has also been recently recorded in the Ulugurus (Hunter et al. 1996), it is likely that the population size of this species is greater than the 200-1,000 individuals estimated by Collar and Stuart (1985) and all breeding individuals are unlikely to be limited to a single subpopulation (contra Collar et al. 1994). However, this species has only ever been recorded in intact forest at low population densities, and it is likely to be forest-dependent. Therefore, given levels of deforestation in both the lowlands and highlands (Hamilton and Bensted-Smith 1989, Collar et al. 1994), the authors agree with Evans et al. (1994) that the species still strongly merits Vulnerable status $\left(\mathrm{B}_{1}+2 \mathrm{a}, \mathrm{c}\right)$.

\section{Sharpes's Akalat Sheppardia sharpei}

Status and distribution Regionally Near-threatened; restricted-range. Common resident in highland forest at $900-2,600 \mathrm{~m}$ (Keith et al. 1992). The nominate race S. s. sharpei occurs in northern Malawi, and S. s. usambarae is restricted to the Usambaras, Ngurus, Ulugurus and Southern Highlands (Keith et al. 1992).

Records and ecology Lutindi and Kilanga: common; Gombero and Luago: not recorded (probably absent). Given this species's presence in the adjacent Ngurus, it seems surprising that it is absent from the Nguus. East Coast Akalat S. gunningi and Sharpe's Akalat do not occur sympatrically (Keith et al. 1992) and this 
appears to be related to habitat selection. While all previous records of East Coast Akalat in Tanzania and Kenya are from drier, coastal forest, where the species appears to demonstrate some preference for more open understorey (E. Nemeth 1996, unpublished), Sharpe's Akalat is usually recorded in relatively moist highland forest with a dense understorey. The forest at Gombero and Luago was considerably drier than that at Lutindi or Kilanga and had a less dense understorey (Seddon et al. in press), and it may be that in this drier, more open submontane forest, East Coast Akalat replaces Sharpe's Akalat. Considerably more research on both species' ecology is needed before any firm conclusions about this can be made. All individuals ( $n=41$, including 12 net records) were observed in intact forest with a relatively dense understorey. Most field records $(76.2 \%$, $n=21$ ) were of individual birds foraging alone, usually probing in the leaf litter and on two occasions making short flycatching sallies of 1-3 m returning to the same or nearby perch. Association with a mixed-species flock was observed on one occasion when an akalat was observed flycatching in the understorey with Square-tailed Drongo, Dark-backed Weaver and Tiny Greenbul Phyllastrephus debilis. A pair were observed attempting to copulate on 18 July 1995.

Conservation These records, together with those of Cordeiro (in press) suggest a preference for relatively intact submontane forest with a reasonably dense understorey, indicating that the species may be susceptible to forest degradation. Therefore although this species should continue to be monitored, its apparently healthy population in Nilo FR and its relatively wide geographical range indicate that it is under no immediate threat of extinction.

\section{East Coast Akalat Sheppardia gunningi}

Status and distribution Globally Vulnerable, regionally Endangered. The nominate race $S$. g. gunning $i$ is found in small, mainly coastal lowland forests around Beira in Mozambique. S. g. bensoni occurs at $475^{-1,750} \mathrm{~m}$ in northern Malawi; and S. g. sokokensis is found up to $300 \mathrm{~m}$ in Kenya and up to $800 \mathrm{~m}$ in north-east Tanzania in the East Usambaras, Pugu Hills, Rondo Plateau, Dondwe forest, and Zanzibar (Keith et al. 1992, Collar et al. 1994).

Records and ecology Lutindi and Kilanga: not recorded (probably absent); Gombero and Luago: fairly common. These are the first records of this species in submontane forest outside Malawi and they represent both a range extension in the Eastern Arc Mountains and an upward altitudinal range extension of $700 \mathrm{~m}$ in Tanzania. All records ( $n=72$, including 21 net records) were in intact submontane forest along streams or in areas with dense undergrowth. Pairs were observed on three occasions, the remainder of the records being of single birds. East Coast Akalats were usually observed on the ground probing amongst leaf litter apparently foraging on berries and seeds (contra Keith et al. 1992, who note this species as being purely insectivorous). In contrast to Clancey (1969) who stated that this species commonly foraged with other species, such as Redcapped Robin Chat Cossypha natalensis, only one individual was observed foraging in loose association with a mixed-species flock. Individuals emitted a vari- 
Table 3. Comparison of the biometrics (ranges with means in brackets) of the East Coast Akalat Sheppardia gunningi from Nguu North FR with published data for the races (Keith et al. 1992)

\begin{tabular}{|c|c|c|c|c|}
\hline & Mass (g) & Wing $(\mathrm{mm})$ & Bill $(\mathrm{mm})$ & Tarsus (mm) \\
\hline $\begin{array}{l}\text { Nguu North } F^{\text {a }} \\
\text { both sexes }\end{array}$ & $\begin{array}{l}14.5-20(17.3) \\
n=20\end{array}$ & $\begin{array}{l}66-79(73.4) \\
n=20\end{array}$ & $\begin{array}{l}13-15(14) \\
n=20\end{array}$ & $\begin{array}{l}21-24(22.6) \\
n=20\end{array}$ \\
\hline S. g. gunningi & & & & \\
\hline male & $\begin{array}{l}17^{-19}(18.0) \\
n=18\end{array}$ & $\begin{array}{l}72-76(74.1) \\
n=13\end{array}$ & $\begin{array}{l}15^{-17}(16.0) \\
n=4\end{array}$ & $\begin{array}{l}21,22 \\
n=2\end{array}$ \\
\hline female & $\begin{array}{l}16-17(16.7) \\
n=3\end{array}$ & $\begin{array}{l}65-68(67.2) \\
n=4\end{array}$ & $\begin{array}{l}15^{-16}(1.5 .2) \\
n=3\end{array}$ & $\begin{array}{l}20,20 \\
n=2\end{array}$ \\
\hline $\begin{array}{l}\text { S. g. sokokensis } \\
\text { males }\end{array}$ & $\begin{array}{l}13,17 \\
n=2\end{array}$ & $\begin{array}{l}67-72(70.5) \\
n=11\end{array}$ & & \\
\hline females & $\begin{array}{l}12-15(13.5) \\
n=4\end{array}$ & $\begin{array}{l}63-72(65.6) \\
n=7\end{array}$ & & \\
\hline $\begin{array}{l}\text { S. g. bensoni } \\
\text { males }\end{array}$ & : & $\begin{array}{l}72-78(74.8) \\
n=8\end{array}$ & & \\
\hline female & & $\begin{array}{l}68-70(69) \\
n=3\end{array}$ & & \\
\hline
\end{tabular}

${ }^{a}$ Wing lengths measured by maximum chord to the nearest $0.5 \mathrm{~mm}$, bill measurements taken from bill tip to skull, mass to nearest $0.5 \mathrm{~g}$.

ety of calls, including a far-carrying, siren-like call comprising two notes (not previously noted for this species), a guttural clicking call usually accompanied by tail-pumping, and a song comprising a soft, plaintive oscillating whistle. The siren-like call is possibly a long-distance contact call, and two individuals were occasionally heard calling to each other. The plumage did not differ significantly from that described for East Coast Akalat in Keith et al. (1992). The biometrics of the 20 individuals mist-netted (Table 3) are closer to those of S. g. bensoni, which is slightly larger than either S. g. gunningi or S. g. sokokensis. Given that S. g. bensoni occurs $800 \mathrm{~km}$ to the south in Malawi it is possible that the Nguu records represent a new subspecies; further work is needed to ascertain this.

Conservation It is very likely that East Coast Akalat occurs throughout the Nguus, especially given the amount of suitable habitat. As other sites are small or have tiny populations (T. Evans, in litt. 1995), it is very likely that the Nguus may hold at least the largest population of East Coast Akalat in Tanzania. However, accurate population estimates in the Nguus are urgently required. These records, together with those of E. Nemeth (1996, unpublished) who has estimated the population of this species in the Arabuko-Sokoke forest in Kenya at 20,000 individuals, strongly suggest that this species is less threatened with extinction than previously thought. It may require revision of its conservation status to globally Near-threatened.

\section{Evergreen Forest Warbler Bradypterus barratti}

Status and distribution Regionally Near-threatened. Endemic and localized resident of dense undergrowth in montane forest mainly at 900-3,000 $\mathrm{m}$ in west, east and south-central Africa (Urban et al. 1997). 
Records and ecology Lutindi and Kilanga: abundant; Gombero and Luago: common. These records in the Nguus represent a new locality for this species. All records were from the low storey of intact submontane forest and forest-edge. A highly vocal but elusive species.

Conservation Although our records indicate some preference for intact forest, Cordeiro (in press) recorded this species as common in the dense understorey of secondary and degraded forest. This suggests that it is able to withstand some habitat degradation, providing a dense understorey is present. Furthermore, Evergreen Forest Warbler has a wide geographic range. It is therefore under no threat of regional extinction at least in the near future, although its populations should be monitored.

\section{Usambara (Southern) Hyliota Hyliota (australis) usambarae}

Status and distribution Regionally Endangered. The race $H$. a. slatini occurs in the north-east of the Democratic Republic of Congo, west Uganda and west Kenya; $H$. a. australis is known from Zimbabwe and Mozambique; $H$. a. inornatus is found in Angola through to northwest Mozambique; and the race H. a. usambarae was previously only known from forest at $350-1,000 \mathrm{~m}$ in the Usambaras (Urban et al. 1997). The taxonomy of this species is still unclear. Some authors treat it as an isolated subspecies of Southern Hyliota (Sibley and Monroe 1993, Zimmerman et al. 1996) others have elevated it to specific status (Urban et al. 1997).

Records and ecology Lutindi and Kilanga: rare; Gombero and Luago: not recorded (probably absent as the Nguus are well south of this species known range). These records represent an upwards altitude extension of $200 \mathrm{~m}$ in the East Usambaras. This species was recorded both singly and in pairs, usually in the canopy of mature trees in forest-edge habitat, and was observed in a mixedspecies flock on one occasion. Our observations of apparently monomorphic pairs (cf. H. australis which is sexually dimorphic, the female having brown dorsal plumage) matches those of previous workers (see Urban et al. 1997) from elsewhere in the East and West Usambaras, and lend some support to this hyliota being elevated to specific status.

Conservation As a separate species, the Usambara Hyliota merits urgent conservation attention. Specifically, its extremely small range, very small population size, its tendency to inhabit the canopy of mature trees (this paper, Urban et al. 1997), and the likely decline in the area and quality of its forest and forest-edge habitat means that it will fully warrant Endangered status $\left(B_{1}+2 a, c ; C_{1}\right)$.

\section{Red-capped Forest Warbler Orthotomus metopias}

Status and distribution Restricted-range. Inhabits dense understorey in forest and forest edge at 1,000-2,500 $\mathrm{m}$ in east Tanzania (Usambaras, Ngurus, Ukagurus, Udzungwas, Ukagurus and Southern Highlands) and north-west Mozambique 
(Urban et al. 1997). There are few records from the East Usambaras, the most recent being those of Newmark (1991) and Cordeiro (in press), possibly due to the concentration of fieldwork in unsuitable habitat in the Amani area.

Records and ecology Lutindi: common; Kilanga: rare; Gombero and Luago: not recorded (probably absent). This species's absence from the Nguus is surprising given its presence in the Ngurus. Urban et al. (1997) note that this warbler usually inhabits wet forest with a dense undergrowth and therefore it is possible that the relatively dry, open forest habitat at Gombero and Luago is unsuitable for it . Apart from one individual which was recorded in degraded secondary forest, all individuals ( $n=41$, including two net records) were observed in intact submontane forest and forest edge. Similarly, N. J. Cordeiro (in litt. 1995) only recorded $4-6$ individuals in degraded forest compared with $15-20$ individuals in relatively intact forest. This species was observed mainly (95.1\% of records) foraging in dense understorey at $0.1-1.5 \mathrm{~m}$, and was twice observed in climbers at $3 \mathrm{~m}$. Red-capped Forest Warblers were often encountered foraging in groups of two or three with Bar-throated Apalis Apalis thoracica and Evergreen Forest Warbler and were observed in mixed-species flocks on two occasions. While in such flocks, this warbler gave an alarm call, a high pitched "chirrup", to which the nearby birds responded. The birds were generally extremely vocal and emitted a series of "chirrups" while flitting between branches in the undergrowth.

Conservation The species has been classed as forest-dependent by some workers (Newmark 1991) and it is probably sensitive to forest degradation, in particular clearance of the understorey. Not only does it have a restricted range, but there have been few records from the East Usambaras in recent years. Therefore, while this species is not currently under any threat, it should continue to be monitored.

\section{Spot-throat Modulatrix stictigula}

Status and distribution Restricted-range. Resident in montane forest mainly above $1,200 \mathrm{~m}$ in Tanzania and northern Malawi. The nominate race $M$. s. stictig$u l a$ is found in the Ngurus, Ukagurus and Usambaras, whilst the race $M$. s. pressa is found in the Ulugurus, Songea, Njombe and Mount Rungwe, south-west Tanzania, and the Misuku Hills, north Malawi (Keith et al. 1992).

Records and ecology Lutindi and Kilanga: abundant; Gombero and Luago: not recorded (probably absent). Although it may at first seem surprising that this species is absent from the Nguus given its presence in the Ngurus, Spot-throats mainly inhabit montane forest above $1,200 \mathrm{~m}$ (Keith et al. 1992) and therefore it is possible that the relatively dry forest of the Nguus is unsuitable. Spot-throats were classed as abundant on the basis of records of its high-pitched, two-note whistling call which was a ubiquitous sound of the understorey of intact submontane forest. Two individuals were observed in the field, calling antiphonally from a perch at $<0.5 \mathrm{~m}$ in dense undergrowth, and seven individuals were netted. In the hand, the birds were noted to have the less distinct spotting on the chin and throat that is characteristic of the race M. s. stictigula (Keith et al. 1992). 
Conservation These records, and those of Cordeiro (in press), were from the dense understorey of intact submontane forest which suggests that this species may be sensitive to habitat degradation (contra Keith et al. 1992). Although Britton (1980) stated that there has been an overall decline of the nominate race in the Ngurus and East Usambaras it is possible that insufficient work has been carried out in appropriate habitat in these areas (N. J. Cordeiro, in litt. 1995). The fact that Spot-throat was apparently abundant in Nilo FR but has been classified as rare elsewhere in the Usambaras (Zimmerman et al. 1996), presumably due to the lack of suitable habitat, suggests that Mount Nilo FR is a particularly important site for this species. While it is not under any immediate threat of extinction it remains of conservation importance.

Uluguru Violet-backed Sunbird Anthreptes neglectus

Status and distribution Regionally Vulnerable. Inhabits forest and forest edge up to $1,800 \mathrm{~m}$ and is known from several forest sites in eastern Tanzania and northern Mozambique, with a few records from coastal Kenya (Hall and Moreau 1970, Britton 1980).

Records and ecology Lutindi and Kilanga: rare; Gombero and Luago: uncommon. The records of this sunbird in the Nguus represent a new locality. This sunbird was mainly recorded $(83.7 \%$ of records, $n=43)$ in intact submontane forest, but was also recorded ( $16.3 \%$ of records) in heavily degraded forest and cultivated areas. It tended to forage at $1-5 \mathrm{~m}$ in the undergrowth and mid-storey, and on several occasions was observed probing amongst Loranthus spp. and other flowering plants. It was occasionally observed in mixed-species flocks. In addition, at Kilanga there were two records of sunbirds that differed from A. neglectus described in Mackworth-Praed and Grant (1962) and instead fitted descriptions for female Violet-backed Sunbird A. longuemarei: they were brown above with a bold white supercilium, and very pale yellow on the belly and vent (cf. female A. neglectus which is violet above, lacks a supercilium and is darker yellow on the belly and vent). However, Evans (1996) notes that the juvenile plumage of $A$. neglectus is misleadingly described in Mackworth-Praed and Grant (1962), and that immature $A$. neglectus actually have a bold white supercilium, a dusky brown crown, mantle and wing-coverts, and lemon yellow on the belly and vent. Given that $A$. neglectus and $A$. longuemarei are largely allopatric, with different ranges and habitat preferences (Britton 1980), it is likely that these two records refer to juveniles of $A$. neglectus.

Conservation These records indicate that the extent of occurrence and the population of this sunbird is larger than previously known. Furthermore, its presence in degraded forest and cultivated land suggest that it is able to withstand some habitat degradation, at least in the short term. Therefore, while this sunbird should continue to be monitored, it may be more appropriately classified as regionally Near-threatened. 
Amani Sunbird Anthreptes pallidigaster

Status and distribution Globally and regionally Vulnerable; restricted-range. Limited to one site in Kenya $\left(67 \mathrm{~km}^{2}\right.$ of coastal Brachystegia woodland in the Arabuko-Sokoke forest), and two sites in Tanzania: the Udzungwas at 1,350$1,400 \mathrm{~m}$ (Dinesen et al. ${ }_{1993}$ ) and in the East Usambaras previously only up to $900 \mathrm{~m}$ (Collar and Stuart 1985, Hipkiss et al. 1994).

Records and ecology Lutindi and Kilanga: fairly common; Gombero and Luago: not recorded (probably absent). These records, together with those of Cordeiro (in press), represent an upward altitudinal range extension of $350 \mathrm{~m}$ in the East Usambaras. In Kilanga all individuals were observed at $20-30 \mathrm{~m}$ in the subcanopy and canopy of mature trees within intact submontane forest. In Lutindi, however, Amani sunbirds were also observed at $1-6 \mathrm{~m}$ in the mid-storey in a clearing in heavily degraded forest. This species was mainly observed in pairs ( $76.4 \%$ of individuals, $n=34$ ); only males were observed alone. This species is noted as being mainly nectarivorous (Collar and Stuart 1985); however, it was mainly observed gleaning for insects, probing underneath leaves or amongst lichens and mosses. It regularly ( $73.5 \%$ of individuals) foraged alongside Yellow White-eye Zosterops senegalensis and Collared Sunbird Anthreptes collaris, and on two occasions with Banded Green Sunbird Anthreptes rubritorques. Aggressive interactions, involving chases and a series of loud "chips", were observed between Amani and Collared Sunbirds. Fighting between them has been noted by other workers and it is possible that competition between these species is partly responsible for the decline of Amani Sunbird (Collar and Stuart 1985). On six occasions, this species was encountered feeding by probing lichen-covered branches and gleaning or sally-gleaning in mixed-species flocks comprising Grey Cuckooshrike, Olive Sunbird, Olive Woodpecker, Shelley's Greenbul, Squaretailed Drongo, Tiny Greenbul and White-tailed Crested Flycatcher. Of these flocks, $83.3 \%$ were encountered in the canopy.

Conservation These records indicate that the population of this sunbird is larger than previously thought. However, given that it has a small, fragmented range, occurs at low population densities within this range, may be essentially a canopy specialist preferring intact forest (Collar et al. 1994) and the pressures upon its habitat are great, this species fully merits its Vulnerable status $\left(B_{1}+2 b, c\right)$.

\section{Banded Green Sunbird Anthreptes rubritorques}

Status and distribution Globally and regionally Vulnerable; restricted-range. Previously only known from four areas: the Usambaras, Ngurus, Ulugurus and Udzungwas (Collar et al. 1994). Inhabits the canopy in forest and at the forestedge mainly at $750-1,500 \mathrm{~m}$, but it was recently recorded at $200 \mathrm{~m}$ in the East Usambaras (Hipkiss et al. 1994), with a breeding record at $300 \mathrm{~m}$ (Evans in press). Considered to be scarce throughout the rest of its range (Collar et al. 1994).

Records and ecology All sites: uncommon. These records in the Nguus represent a new locality for this species. This species was recorded in intact submontane 
forest, secondary forest clearings, and in the ecotone between submontane and miombo woodland. Most birds $(73.6 \%, n=38)$ were observed in the subcanopy and canopy of mature trees either in forest clearings within the FR or at the forest edge. Although $78 \%(n=9)$ of the individuals recorded at Lutindi were foraging in low scrub vegetation adjacent to a small maize plantation in the public land, they were always recorded in the vicinity of a few remaining mature trees. All of the Gombero and Luago records were from within or at the edge of intact submontane forest. At Luago, a Banded Green Sunbird was observed feeding on the nectar of Erythrina abyssinica previously noted to be a food plant of this species (Collar and Stuart 1985). The bird was observed feeding intermittently on this plant between about 08 hoo and 16 hoo on seven consecutive days. On all other occasions, it was seen gleaning for insects amongst mosses, leaves and lichen, and was often seen foraging with other sunbirds, commonly Uluguru Violet-backed Sunbird and Olive Sunbird Nectarinia olivacea. On one occasion Banded Green Sunbirds were observed within a large mixed-species flock comprising Square-tailed Drongo, Dark-backed Weaver, Olive Woodpecker, Grey Cuckooshrike and White-tailed Crested Flycatcher. From 25 August to 6 September 1995 two pairs of sunbirds were observed constructing nests in the canopy of mature trees Newtonia sp. at Gombero and Luago at 1,500 $\mathrm{m}$ and 1,280 $m$ respectively. In both cases, the female was observed gathering lichen and the feathery bracts of a flowering climber. The male followed the female giving a high-pitched plaintive "chip" or "teuu" at a frequency of one per second for 30 to 60 seconds. This pattern of active female and watching male was also observed by Moreau and Moreau (1937) and Evans (in press).

Conservation Although these records in the Nguus indicate that the range and population of this species is larger than previously thought, and that it may be tolerant to some degree of habitat disturbance, it still requires tall, mature forest trees. Therefore we agree with Collar and Stuart (1985) that while this sunbird may be able to survive in partly degraded secondary habitats in the short term, its long-term survival is not assured: its range is small and fragmented, the quality and extent of its habitat is declining and it occurs at low population densities. Vulnerable $\left(B_{1}+2 b, c\right)$ therefore remains the most appropriate classification of its status.

\section{Moreau's Sunbird Nectarinia moreaui}

Status and distribution Globally Near-threatened; restricted-range. Previously known from moist forest above 1,300 $\mathrm{m}$ in the Ngurus, Udzungwas, Uvindudas and Ukagurus (where there is a healthy population, Evans and Anderson 1993). Considered a possible hybrid between Loveridge's Sunbird $N$. loveridigei and Eastern Double-collared Sunbird N. mediocris by Sibley and Monroe (1990), but as a full species by Collar and Stuart (1985) and Collar et al. (1994).

Records and ecology Lutindi, Kilanga: not recorded (probably absent); Gombero: rare; Luago: not recorded (possibly overlooked). These records in the Nguus represent an approximately $50-\mathrm{km}$ range extension north-west. All sight records 
of this species were in a clearing in intact submontane forest and are thought to refer to at least one pair and one male. In addition a male was netted in the understorey of intact submontane forest at $1,360 \mathrm{~m}$. The sunbirds were observed between o7hoo and 10h40, foraging in the mid-storey at $1-3 \mathrm{~m}$ on the nectar of flowering climbers. The male was observed collecting water from the surface of lichen in the canopy of a leafless Albizia sp., and appeared to be traplining (see Giles and Wolf 1977) between three climbers. While no female vocalizations were heard, the male regularly emitted a long series of sharp "chirps" at a frequency of one every two seconds whilst perched on an exposed branch. Moreau's Sunbird was observed foraging in the vicinity of Banded Green Sunbirds, but no direct interactions were observed.

Conservation This species is likely to occur in other parts of the Nguus and it is possible that this mountain range supports a significant population. Further surveys and population estimates should be made in other forested areas in the mountain range. These observations indicate that this species's habitat requirements may be similar to those of Banded Green Sunbird and therefore, although the population of this species may be greater than previously estimated, Nearthreatened remains the most suitable classification of its status.

\section{Kenrick's Starling Poeoptera kenricki}

Status and distribution Restricted-range. Common in highland forest at 900-2,500 $m$ in central Kenya and eastern Tanzania (Zimmerman et al. 1996). Occurs down to $300 \mathrm{~m}$ in the non-breeding period (T. Evans, in litt. 1995).

Records and ecology Lutindi and Kilanga: uncommon; Gombero: uncommon; Luago: rare. These records in the Nguus represent a new locality for this species. Recorded in intact, degraded and forest-edge habitat, this species was predominantly $(82.4 \%$ of records, $n=31)$ observed at $20-40 \mathrm{~m}$ in the canopy of mature submontane forest trees such as Albizia spp. Starlings were usually observed gleaning for insects amongst lichen, epiphytes and mosses, and perched for periods up to 45 minutes in the outermost dead branches. While pairs were usually recorded ( $45.2 \%$ of individuals), a flock of seven birds was observed on one occasion. Evidence of breeding was noted on 24 and 25 August 1995 at Gombero at $1,500 \mathrm{~m}$ : a pair was observed bringing nesting material to a hole in a dead tree at $10 \mathrm{~m}$ above the ground.

Conservation These observations indicate that this starling may be a canopy specialist and perhaps may require holes in mature forest trees for breeding. These records in the Nguus confirm its presence throughout the Eastern Arc Mountains and thus the fact that it is under no imminent threat of extinction. However, as it may be sensitive to the removal of mature trees, and levels of deforestation are high in its restricted range, this species should continue to be monitored.

\section{Usambara Weaver Ploceus nicolli}

Status and distribution Globally Vulnerable, regionally Endangered; restrictedrange. The nominate race $P$. n. nicolli is endemic to the East and West Usambaras 
and occurs at $900-2,200 \mathrm{~m}, P$. n. anderseni is known from the Ulugurus and Udzungwas at 1,100-2,150 m (Stuart et al. 1987, Jensen and Brøgger-Jensen 1992, Dinesen et al. 1993). It mainly inhabits the canopy of evergreen montane forest, but has also been noted on forest edge and in isolated trees in cultivated areas (e.g. T. A. van der Willigen and J. C. Lovett, 1981, unpublished).

Records and ecology Lutindi and Kilanga: fairly common; Gombero and Luago: not recorded. Weavers were observed in the canopy and subcanopy at $20-40 \mathrm{~m}$ in mature trees of Albizia spp. and Newtonia spp. Observations were made either in clearings in otherwise intact submontane forest $(33.3 \%$ of records, $n=12$ ) or in cultivated public land where mature trees still stood (66.7\% of records). Single males or pairs of birds were usually observed gleaning for insects amongst moss, lichens and epiphytes. On three occasions, the weavers were encountered in mixed-species flocks comprising Grey Cuckooshrike, Square-tailed Drongo, Yellow-throated Woodland Warbler, Many-coloured Bush-shrike Malaconotus multicolor, White-tailed Crested Flycatcher and Olive Sunbird. Such association with flocks has been noted by previous workers (e.g. D. A. Turner, 1978, unpublished, S. N. Stuart and T. A. van der Willigen, 1979, unpublished), but was not observed by Cordeiro (in press). Interestingly, the colour of the forehead varied between individuals from yellow-green to yellow washed with chestnut. Furthermore, the extent of this colouration varied from indistinct to very conspicuous. It is likely that these differences are age related.

Conservation Until it was observed just outside what was then Lutindi FR in 1994 (Cordeiro in press), Usambara Weaver had not been recorded in the East Usambaras since 1932 when it was last seen at Amani (Sclater and Moreau 19321933). The lack of sightings since 1932 led various authors to suggest that the species was locally extinct (e.g. Collar and Stuart 1985, Evans and Anderson 1993). Our records and those of Cordeiro (in press) indicate that Nilo FR is very likely to represent the last remaining stronghold in the East Usambaras for the nominate race. These records indicate that the total population of this species may be greater than 1000 individuals (contra Collar et al. 1994), although accurate population surveys are required throughout its range. High levels of forest degradation were found within and around Nilo FR and although individuals have been observed in cultivated land, they were always in areas where mature trees still stood. The few small remaining populations of this weaver are threatened by the deforestation taking place within its small, fragmented range, and it therefore merits Vulnerable status $\left(\mathrm{B}_{1}+2 \mathrm{~b}, \mathrm{c} ; \mathrm{C} 2 \mathrm{a}\right)$.

\section{Conclusions}

Sixteen species of conservation interest were recorded during fieldwork including five Vulnerable, three Near-threatened, one regionally Endangered, one regionally Vulnerable, two regionally Near-threatened and to in total as restricted-range species. New information on these species' ecology is presented in this paper. We recommend that the classification of the conservation status of three species be revised. The discovery in the Nguus of what is likely to be the largest population of East Coast Akalat, at least in Tanzania, means that the range and the population of this species is greater than originally thought, and 
it is recommended that it be considered for demotion from Vulnerable to Nearthreatened status. The presence of Uluguru Violet-backed Sunbird in the Nguus indicates that the range and population of this species is also greater than previously estimated. Furthermore there is some evidence to suggest that the species is able to withstand some habitat degradation in the short term. It is therefore suggested that this species might be more appropriately considered as regionally Near-threatened as opposed to regionally Vulnerable. Finally, if treated as a separate species, it is recommended that on the basis of its extremely small range, very small population size and the likely decline in the area and quality of its forest and forest-edge habitat, Usambara Hyliota warrants at least Endangered status.

Four other Vulnerable species were recorded: Usambara Eagle Owl, Amani Sunbird and Usambara Weaver in Nilo FR, and Banded Green Sunbird in both FRs. All four should retain their Vulnerable status as all have small, fragmented ranges, occur at low population densities, and would appear to be dependent on intact forest which is declining in area.

Nguu North FR represents a new locality for several species of conservation interest, indicating that the range and hence the population of these species is greater than previously thought. However, no status changes are recommended as most species appear either to have some preference for intact forest, or to require tall, mature forest trees, and thus should continue to be monitored.

Interestingly, Sharpe's Akalat, Spot-throat and Red-capped Forest Warbler were not recorded in Nguu North FR, and are probably absent from the Nguus. Given that they have been recorded in the adjacent Ngurus, this is surprising. All three species are usually recorded in moist, montane forest with a dense understorey, and their absence from Nguu North FR may be related to the fact that the forest seemed dry and to have a less dense understorey (Seddon et al. in press). In the case of Sharpe's Akalat, it is also possible that in this relatively dry submontane forest, competition with East Coast Akalat which is usually recorded in drier, more open forest, may have determined its absence from this mountain range.

The ecology of these forests is sufficiently well known for management initiatives to be instigated immediately. For an outline of practical recommendations for the management of these FRs see Seddon et al. (in press). Furthermore, there are several lines of ecological investigation which should be undertaken. In Nilo FR, the populations densities of Usambara Weaver and Usambara Eagle Owl in particular need to be estimated, and their ecological requirements more accurately determined. Further searches for the Long-billed Tailorbird, recorded by Cordeiro (in press) at Lutindi in 1994 are also urgently required. In Nguu North FR, it is recommended that more accurate population density surveys of East Coast Akalat and Moreau's Sunbird are conducted. Prior to this work, the Nguu Mountains were poorly known and underrated in terms of their biological and conservation importance. Therefore, it is strongly recommended that more surveys encompassing a broad range of taxa are carried out both in Nguu North FR and the adjacent Derema and Kilindi FRs, which support submontane forest at c. $1,000-1,600 \mathrm{~m}$. It is believed that these forests may hold important further populations of birds and other animals and plants of conservation interest.

Any further ecological research in these areas must be undertaken in conjunc- 
tion with sociological work. Not only should environmental education activities be started in the villages adjacent to the FRs (e.g. Kwemkole, Kizara, Gombero and Luago), but detailed studies of resource use in these settlements are desperately needed. Such studies will enable conservationists to understand better the present relationship between the settlements and the forests, and should clarify the mechanisms by which a more sustainable relationship can be developed.

\section{Acknowledgements}

All advisors and sponsors of our work are fully acknowledged in N. Seddon et al. (1995, unpublished report), available from Nathalie Seddon at the address below. We thank particularly the Tanzanian Commission for Science and Technology, the Ministry of Forestry and Mr M. I. L. Katigula for permitting us to conduct research in the East Usambara and Nguu Mountains. Our sincerest thanks also go to Neil Burgess, Tom Evans, Lincoln Fishpool, Kim Howell, Andy Perkin and Alan Tye. In Tanzania, we thank Neil Baker, Stan Davies and all the staff at the Wildlife Conservation Society of Tanzania and at the East Usambara Catchment Forestry Project. Finally, special thanks go to Stu Butchart and Norbert Cordeiro for helpful discussions and comments on this manuscript and to an anonymous referee for many constructive criticisms.

\section{References}

Bennun, L. A. and Njoroge, P. K. (1996) Birds to watch in East Africa: a preliminary Red Data list. Research reports of the centre for biodiversity, National Museums of Kenya: Ornithology, 23.

Bibby, C. J., Burgess, N. D. and Hill, D. A. (1992) Bird census techniques. London: Academic Press.

Britton, P. L. (1980) The birds of East Africa, their status and distribution. Nairobi: East African Natural History Society.

Brown, L., Urban, E. K. and Newman, K. (1982) The birds of Africa,1. London: Academic Press.

Clancey, P. A. (1969) The status of Gunning's Robin. Ostrich 40: 19-20.

Collar, N. J. and Stuart, S. N. (1985) Threatened birds of Africa: the ICBP/IUCN red data book. Cambridge, U.K.: International Council for Bird Preservation.

Collar, N. J., Crosby, M. J. and Stattersfield, A. J. (1994) Birds to watch 2: the world list of threatened birds. Cambridge, U.K.: BirdLife International.

Cordeiro, N. J. (in press) A preliminary survey of the montane avifauna of Mt Nilo, East Usambaras, Tanzania. Scopus.

Cordeiro, N. J. and Githiru M. (in press) Avifauna of the Brachylaena woodlands in the Usambara lowlands. Bull. $A B C$.

Dinesen, L., Lehmberg, T., Svendsen, J. O. and Hansen, L. A. (1993) Range extensions and other notes on some restricted-range forest birds from West Kilombero in the Udzungwa Mountains, Tanzania. Scopus 17: 48-59.

Dowset, R. J. and Dowset-Lemaire, F. (1993) A contribution to the distribution and taxonomy of Afrotropical and Malagasy birds. Belgium: Tauraco Press (Tauraco Res. Rep. 5).

Evans, T. D. (in press) Records from the East Usambara lowlands. Scopus.

Evans, T. D. (1996) Note on the field identification of Uluguru Violet-backed Sunbird Anthreptes neglectus. Bull. ABC 3: 38-39.

Evans, T. D. and Anderson, G. (1993) Results of a wildlife survey in East Usambara and Ukaguru Mountains, Tanzania. Scopus 17: 40-47.

Evans, T. D., Watson, L. G., Hipkiss, A. J., Kiure, J., Timmins, J. R. and Perkin, A. W. (1994) 
New records of Sokoke Scops Owl Otus ireneae, Usambara Eagle Owl Bubo vosseleri, and East Coast Akalat Sheppardia gunningi from Tanzania. Scopus 18: 40-47.

Fjeldså, J. and Lovett, J. (1997) Geographical patterns of old and young species in African forest biota: the significance of specific montane areas as evolutionary centres. Biodiv. Conserv. 6: 325-246.

Fry, C. H., Keith, S. and Urban, E. K. (1988) The birds of Africa, 3. London: Academic Press. Giles, F. B. and Wolf, L. L. (1977) Nonrandom foraging by sunbirds in a patchy environment. Ecology 58: 1284-1296.

Hamilton, A. and Bensted-Smith, R. (1989) Forest conservation in the East Usambara Mountains, Tanzania. Gland, Switzerland and Forestry Division, Ministry of Lands, Natural Resources and Tourism, Tanzania: IUCN.

Hall, B. P. and Moreau, R. E. (1970) An atlas of speciation in African passerine birds. London: British Museum (Natural History).

Hipkiss, A. J., Watson, L. G. and Evans, T. D. (1994) The Cambridge-Tanzania Rainforest Project 1992: brief account of ornithological results and conservation proposals. Ibis 136: 107-108.

Hunter, N., Carter, C. and Mlunga, E. (1996) Recent observations in the Udzungwa and Uluguru Mountains, Central Tanzania. Bull. $A B C$ 3: 96-98.

ICBP (1992) Putting biodiversity on the map. Cambridge, U.K.: International Council for Bird Preservation.

Jensen, F. P. and Brøgger-Jensen, S. (1992) The forest avifauna of the Udzungwa Mountains, Tanzania. Scopus 15: 65-83.

Keith, S., Urban, E. K. and Fry, C. H. (1992) The birds of Africa, 4. London: Academic Press.

Mace, G. and Stuart, S. (1994) Draft IUCN threatened species categories. Species 21-22: 13-24.

Mackworth-Praed, C. W. and Grant, C. H. B. (1962) African handbook of birds: the birds of eastern and north-eastern Africa. London: Longmans.

Moreau, R. E. (1935) A synecological study of Usambara, Tanganyika territory, with particular reference to birds. J. Ecql. 23: 1-43.

Moreau, R. E. (1964) The rediscovery of an African owl Bubo vosseleri. Bull. Brit. Orn. Club 84: 47-52.

Moreau, R. E. and Moreau, W. M. (1937) Biological and other notes on some East African Birds. Ibis 14: 152-174, 321-345.

Newmark, W. D.(1991) Tropical forest fragmentation and the local extinction of understorey birds in the Eastern Usambara mountains, Tanzania. Conserv. Biol. 3: 67-78.

Sclater, S. and Moreau, R. E. (1932-1933) Taxonomic and field notes of some birds of the north-east Tanganyika territory. Ibis 13 Series 2: 487-522 and 656-683, 1932; Series 3: 133, 187-219 and 399-440, 1933 .

Seddon, N., Capper, D. R., Ekstrom, J. M., Isherwood, I. S., Muna, R., Pople, R. G., Tarimo, E. and Timothy, J. (in press) The importance of Nilo and Nguu North Forest Reserves for the conservation of montane forest birds in Tanzania. Biol. Conserv.

Sibley, C. G. and Monroe, B. L. (1990) Distribution and taxonomy of birds of the world. New Haven: Yale University Press.

Stattersfield, A. J., Crosby, M. J., Long, A. J. and Wege, D. C. (1997) Global directory of Endemic Bird Areas. Cambridge, U.K.: BirdLife International (BirdLife Conservation Series).

Stuart, S. N., Jensen, F. P. and Brogger-Jensen, S. (1987) Altitudinal zonation of the avifauna in Mwanihana and Magombera Forests, eastern Tanzania. Gerfault 77: 165-186.

Turner, D. A., Pearson, D. J. and Zimmerman, D. A. (1991). Taxonomic notes on some East African birds, 1. Non-passerines. Scopus 14: 84-91.

Tye, A. (1993) Forest and bird conservation in the East Usambara Mountains, north-east Tanzania In W. T. Wilson, ed. Birds and the African environment: proceedings of the Eight 
Pan-African Ornithological Congress. Ann. Mus. Royal de l'Afrique Centrale (Zoo.) 268: 287292.

Urban, E. K., Fry, H. C. and Keith, S. (1986) The birds of Africa., 2. London: Academic Press.

Urban, E. K., Fry, H. C. and Keith, S. (1997) The birds of Africa, 5. London: Academic Press.

White, C. M. N (1965) A revised checklist of African non-passerine birds. Lusaka: Government Printer.

Zimmerman, D. A., Turner, D. A. and Pearson, D. J. (1996) Birds of Kenya and northern Tanzania. London: Christopher Helm and A \& C Black.

\section{NATHALIE SEDDON}

Department of Zoology, Downing Street, Cambridge, $\mathrm{CB}_{2}{ }_{3} E J$, U.K.

JONATHAN M. M. EKSTROM

Department of Animal and Plant Sciences, Western Bank, Sheffield S1o $2 T N$, U.K.

DAVID R. CAPPER

King's College, Cambridge, CB2 iST, U.K.

ISABEL S. ISHERWOOD

Queens' College, Cambridge, $\mathrm{CB}_{3}$ gET, U.K.

RAYMOND MUNA

East Usambara Catchment Forestry Project, PO Box 5869, Tanga, Tanzania.

ROBERT G. POPLE

Queens' College, Cambridge, $C_{3}$ 9ET, U.K.

ERNESTI TARIMO and JONAS TIMOTHY

Mount Kilimanjiro Forestry Project, PO Box 1826, Moshi, Tanzania. 